\title{
A 39 kD BARLEY SEED PROTEIN OF THE SERPIN SUPERFAMILY INHIBITS $\alpha$-CHYMOTRYPSIN
}

\author{
by \\ ROBERT LUNDGARD ${ }^{1)}$ and BIRTE SVENSSON \\ Department of Chemistry, Carlsberg Laboratory, \\ Gamle Carlsberg Vej 10, DK-2500 Copenhagen Valby \\ "Present address: MilliGen/BioSearch, Division of Millipore Corporation, \\ 81 Digital Drive, Novato, CA 94949-5728, USA
}

Keywords: Barley $\mathrm{Z}$ protein, $\alpha$-chymotrypsin inhibition, serpin reactive-site loop cleavage, amino acid sequence, immunoreactivity

A $39 \mathrm{kD}$ protein has been extracted from barley flour with $0.1 \mathrm{M}$ monothioglycerol at $\mathrm{pH} 5.0$ and purified by $\left(\mathrm{NH}_{4}\right)_{2} \mathrm{SO}_{4}$-precipitation, anion exchange and molecular sieve chromatography. It is an $\mathrm{N}$-terminally blocked, non-glycosylated, single-chain protein present in at least two molecular forms of isoelectric points 5.18 and 5.22. The amino acid composition and partial sequence analysis reveal a relationship to barley endosperm $Z$ protein which belongs to the serpin superfamily. The $39 \mathrm{kD}$ protein inhibits $\alpha$-chymotrypsin while little or no effect could be demonstrated on trypsin, subtilisin, proteinase $\mathrm{K}, \mathrm{S}$. aureus $\mathrm{V} 8$ protease, thermolysin or two malt thiol endoproteinases. The $39 \mathrm{kD}$ protein is immunochemically related to the major protein component in beer.

\section{INTRODUCTION}

The endosperm from seeds of barley and other cereals contains numerous proteins believed to act either during dormancy as inhibitors against endogenous and exogenous hydrolases (5) or play a role as amino acid storage. A relatively abundant one is the lysine-rich barley $\mathrm{Z}$ protein (7-11) that belongs to the serpins, a superfamily of serine proteinase inhibitors $(2,15,16)$. A few serpins have either no recognized function, like chicken ovalbumin (16) and barley $\mathrm{Z}$ protein (11), or have evolved to mammalian hormone carriers such as thyroxine and corticol binding globulins $(4,6)$ or hormone precursors such as the angiotensinogens (18). These serpins, however, are all suscep- tible to irreversible proteolytic cleavage in the reactive center loop $(2,11,25,27)$.

We report here the isolation and preliminary characterization of a $39 \mathrm{kD}$ protein present in aqueous extracts of barley flour. It is structurally related to the earlier described $Z$ protein (7-11), but in contrast to this protein it is able to inhibit $\alpha$-chymotrypsin. Both proteins are immunochemically related to the major antigenic beer protein $(8,9,12)$.

\section{EXPERIMENTAL}

\subsection{Materials}

Barley seeds (Hordeum vulgare L., cv.s Gula and Hiproly) were obtained from Carlsberg

\footnotetext{
Abbreviations: PAGE = polyacrylamide gel electrophoresis; SDS = sodium dodecylsulfate; serpin = serine proteinase inhibitor.
} 
Plant Breeding. Beer protein Fraction $\mathrm{X}$ and corresponding antiserum raised in rabbit (12) were provided by Drs. S.B. SøRENSEN (this department) and P. VAAG, Department of Biotechnology, Carlsberg Research Laboratories, respectively. Two barley malt thiol endoproteinases (19) were kind gifts of Drs. S. KOEHLER and T.-H.D. Ho, Washington University, St. Louis, MO. Benzoyl-L-tyrosine ethyl ester was from Aldrich Chem. Co., Milwaukee, WI, benzoyl-Larginine methyl ester and azocasein were from Sigma Chem. Co., St. Louis, MO. Sepharose-4B and protein A-Sepharose were from Pharmacia, Uppsala, Sweden. Proteinase $\mathrm{K}$ was from Merck, Darmstadt, FRG, other proteases, chemicals and materials were obtained as earlier reported (22).

\subsection{Methods}

\subsubsection{Purification of $39 \mathrm{kD}$ barley seed protein}

Proteins were extracted from barley flour ( 2 $\mathrm{kg}$ ) in the presence of $0.1 \mathrm{M}$ monothioglycerol at pH 5.0 and subsequently fractionated by precipitation between $20-60 \%$ satd. $\left(\mathrm{NH}_{4}\right)_{2} \mathrm{SO}_{4}$ as described previously (21). Redissolved pigments adsorbed onto DEAE-cellulose at $\mathrm{pH} 7.0$ while non-adsorbed proteins were applied to DEAEcellulose DE-52 $(5 \times 21 \mathrm{~cm})$, equilibrated in 15 $\mathrm{mM}$ Tris- $\mathrm{HCl} \mathrm{pH} 8.0$ and eluted by a gradient from zero to $0.1 \mathrm{M} \mathrm{NaCl}$ in the same buffer at a flow rate of $180 \mathrm{ml} \cdot \mathrm{h}^{-1}(21,22)$. The elution of $39 \mathrm{kD}$ protein and $\beta$-amylase 1 overlapped between $0.07 \mathrm{M}$ and $0.08 \mathrm{M} \mathrm{NaCl}$. The proteins were concentrated by ultrafiltration (Amicon $\mathrm{UM} 10$ membrane) to $2 \mathrm{mg} \cdot \mathrm{ml}^{-1}$ (up to this point $0.1 \mathrm{M}$ monothioglycerol was present). Portions $(2 \mathrm{ml})$ were dialyzed against $75 \mathrm{~mm}$ $\mathrm{NaHCO}_{3} \mathrm{pH} 8.0,5 \mathrm{~mm}$ dithiothreitol, made 5\% in glycerol and gel filtered at room temperature on Bio-Gel P-100 $(1.5 \times 87 \mathrm{~cm})$ using the same buffer and a flow rate of $8.2 \mathrm{ml} \cdot \mathrm{h}^{-1}$. Aliquots (approx. $0.5 \mathrm{mg}$ protein) of collected fractions were dried by vacuum centrifugation and analyzed by SDS-PAGE. $39 \mathrm{kD}$ protein obtained was stored in solution at either $4{ }^{\circ} \mathrm{C}$ or $-20^{\circ} \mathrm{C}$ prior to further characterization.

Hiproly barley flour $(700 \mathrm{~g})$ was extracted essentially as above. Proteins precipitating between $45-60 \%$ satd. $\left(\mathrm{NH}_{4}\right)_{2} \mathrm{SO}_{4}$ were collected and subjected to immunoadsorption chromatography on a conjugate ( $5 \mathrm{ml}$ bed volume) prepared by coupling anti-beer protein Fraction $\mathrm{X}$-IgG, isolated from serum using protein ASepharose (14), to Sepharose 4B as earlier described (24). $0.4 \mathrm{M} \mathrm{NaCl}, 0.01 \%$ SDS, pH 7.0 was used for sample application and washing and 0.1 $\mathrm{M}$ glycine, $\mathrm{pH} 2.5$ for elution.

\subsubsection{Isoelectric focusing and gel electrophoresis} Analytical isoelectric focusing in the range $\mathrm{pH}$ 3-9, 10\% slab SDS-PAGE, sample denaturation and reduction, protein staining with Coomassie brilliant blue, $\mathrm{M}_{\mathrm{r}}$ - and pI-estimation using appropriate protein marker kits were performed as earlier described (20-22).

\subsubsection{Preparation and separation of tryptic frag- ments}

$39 \mathrm{kD}$ protein $\left(4 \mathrm{mg} \cdot \mathrm{ml}^{-1}\right.$ in $0.1 \mathrm{M} \mathrm{NH}_{4} \mathrm{HCO}_{3}$ $\mathrm{pH}$ 8.0, $3 \mathrm{M}$ urea) was incubated with trypsin (46 $\left.\mu \mathrm{g} \cdot \mathrm{ml}^{-1}\right)$ for $2 \mathrm{~h}$ at $37^{\circ} \mathrm{C}$. The resulting mixture $(500 \mu \mathrm{l})$ was lyophilized, added $0.1 \%$ trifluoroacetic acid $(400 \mu \mathrm{l})$ and centrifuged $(10000 \times \mathrm{g}$, $10 \mathrm{~min}$ ). The supernatant was subjected to RP-HPLC using a Baker wide-pore C18 (RKP $7104)$ column $(4.6 \times 250 \mathrm{~mm})$ with elution over $60 \mathrm{~min}$ at a flow rate of $0.5 \mathrm{ml} \cdot \mathrm{min}^{-1}$ by a linear gradient of $16-52 \% 1$-propanol in $0.1 \%$ trifluoroacetic acid $(23,29)$. Peptides were monitored at $220 \mathrm{~nm}$ and material in a peak at $32 \%$ 1-propanol was rechromatographed using a shallow gradient leading to a homogeneous peptide fragment.

\subsubsection{Limited proteolysis by $\alpha$-chymotrypsin}

$39 \mathrm{kD}$ protein and $\alpha$-chymotrypsin were incubated for $1 \mathrm{~h}$ at $21^{\circ} \mathrm{C}$ or $28^{\circ} \mathrm{C}$ in $0.1 \mathrm{M}$ Tris pH 8.0. Aliquots of the reaction mixtures were subjected to isoelectric focusing or SDS-PAGE. Prior to denaturation samples for SDS-PAGE were made $6 \mathrm{~mm}$ in diisopropylfluorophosphate and left at $8{ }^{\circ} \mathrm{C}$ overnight to inactivate $\alpha$-chymotrypsin. 


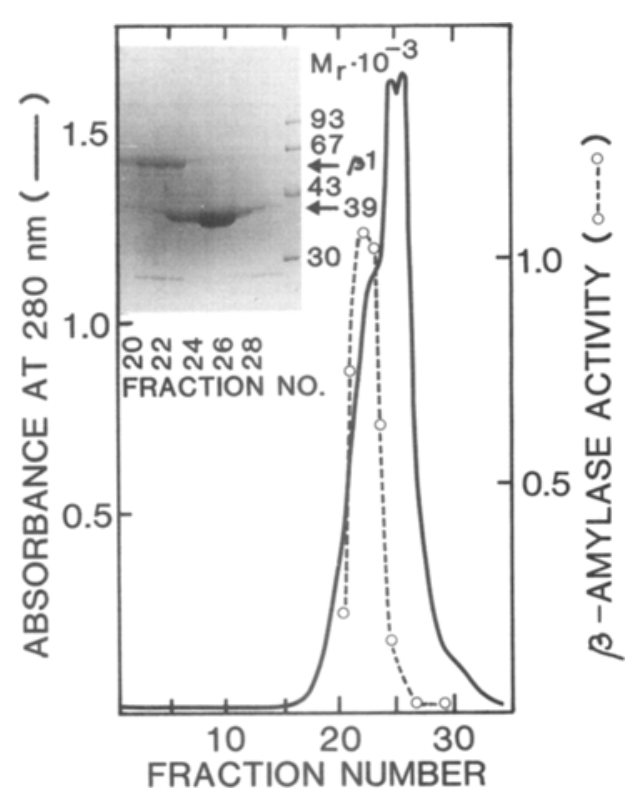

Figure 1. Separation of the $\beta$-amylase 1 ( $\beta 1$ in insert) and $39 \mathrm{kD}$ protein by gel filtration on Bio-Gel P-100 (see 2.2.I). $\beta$-Amylase activity was measured by incubation of $10 \mu 1$ aliquots for $30 \mathrm{~s}$ with $1 \%$ soluble starch essentially as earlier described (21). Fractions 25 and 26 were combined and used for the further characterization of $39 \mathrm{kD}$ protein. The insert shows SDS-PAGE of the indicated amount of protein from fractions 20 ( $10 \mu \mathrm{g}), 21-22(\sim 20 \mu \mathrm{g}), 23-24(\sim 50 \mu \mathrm{g}), 25-26(\sim 100$ $\mu \mathrm{g}), 27(-20 \mu \mathrm{g}), 28-29(-10 \mu \mathrm{g})$.

\subsubsection{Analytical procedures and enzyme assays}

Amino acid analysis was performed on protein $(10 \mu \mathrm{g})$ hydrolyzed for 24,48 and $72 \mathrm{~h}$ as described (29). Half-cystine was determined as cysteic acid after performic acid oxidation (13). The tryptophan content was estimated by second derivative UV spectroscopy (25). Amino acid sequencing of the $39 \mathrm{kD}$ protein was performed on a Beckman automated sequencer $(17,28)$ and of a tryptic fragment on an Applied Biosystems Model 470A gas-phase sequencer, equipped with a Model 120 PTH analyzer. The concentration of $39 \mathrm{kD}$ protein was determined either by amino acid analysis or spectrophotometrically using $E_{280}^{1 \%}=7.7$. Neutral carbohy- drate was examined by the phenol-sulfuric acid procedure (3).

Immunodiffusion using anti-beer protein Fraction X-IgG (see 2.2.1) was performed using a $1 \%$ agarose gel in $25 \mathrm{~mm}$ sodium phosphate $\mathrm{pH}$ $7.0,0.4 \mathrm{M} \mathrm{NaCl}$.

Proteinase inhibition was tested by addition of $39 \mathrm{kD}$ protein in 1.4-14-fold molar excess to the various enzymes $\left(0.9 \mathrm{mg} \cdot \mathrm{ml}^{-1}\right.$ in $0.1 \mathrm{M}$ Tris, $\mathrm{pH}$ $8.01 \mathrm{mM} \mathrm{CaCl}_{2}$ ) and assay of activity before and after this incubation using appropriate substrates as described below.

Esterase activity of $\alpha$-chymotrypsin and trypsin at $\mathrm{pH} 8.0$ was determined spectrophotometrically at $21{ }^{\circ} \mathrm{C}$ employing benzoyl-L-tyrosine ethyl ester and benzoyl-L-arginine methyl ester as substrates, respectively (31-33). Linear rates were followed from zero to $5 \mathrm{~min}$. Endoproteinase activities of $\alpha$-chymotrypsin, trypsin, subtilisin, proteinase $\mathrm{K}, \mathrm{S}$. aureus V8 protease, thermolysin and two thiol endoproteinases from barley malt (19) were measured with $0.1 \%$ azocasein as substrate in $0.1 \mathrm{M}$ Tris- $\mathrm{HCl}, 5 \mathrm{mM} \mathrm{CaCl}_{2}, \mathrm{pH} \mathrm{8.0.} \mathrm{After} \mathrm{incubation}$ up to $40 \mathrm{~min}$ at $25^{\circ} \mathrm{C}$ the reaction was stopped by addition of trichloroacetic acid to $10 \%(\mathrm{w} / \mathrm{v})$. The mixture was left for $30 \mathrm{~min}$, centrifuged and the absorbance of the supernatant measured at $330 \mathrm{~nm}$ against appropriate blanks.

\section{RESULTS}

\subsection{Purification and characterization of the 39 kD barley seed protein}

The $39 \mathrm{kD}$ protein was observed as a minor component in $\beta$-amylase 1 -containing eluate from DEAE-cellulose chromatography (22). Fractions rich in $39 \mathrm{kD}$ protein were pooled and further purified on Bio-Gel P-100 (Figure 1). Essentially pure $39 \mathrm{kD}$ protein was obtained in fractions 25 and 26 (Figure 1) yielding a total of $4 \mathrm{mg}$ from $1 \mathrm{~kg}$ of seeds. Isoelectric focusing demonstrated dominant components of $\mathrm{pI} 5.18$ and 5.22 (see Figure 3). SDS-PAGE resolved the $39 \mathrm{kD}$ from trace amounts of a $38 \mathrm{kD}$ protein (see Figure 4, lane 1), represented perhaps by bands of pI 5.16 and 5.20 (Figure 3).

The amino acid composition of the $39 \mathrm{kD}$ protein (Table I) reveals a close relationship with barley $\mathrm{Z}$ protein which, however, had higher $\mathrm{pI}$ 
a.

$39 \mathrm{kD}$ protein

barley $\mathrm{z}$ protein

b.

$39 \mathrm{kD}$ protein

barley $\mathrm{Z}$ protein

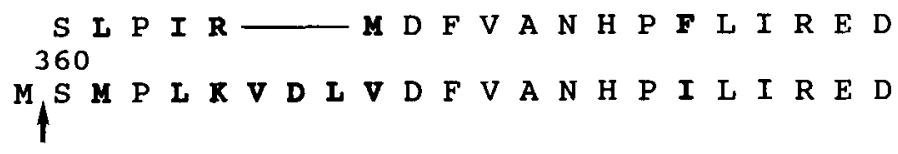

Figure 2. Sequence comparison between barley seed $39 \mathrm{kD}$ protein and $\mathrm{Z}$ protein (11). a. The sequence $C$-terminal to the proteinase sensitive bond (indicated by arrow) in the serpin reactive loop $(2,11,15)$. - matches inserted residues in the $\mathrm{Z}$ protein. b. A tryptic fragment (see 2.2.3). Differences are in bold print.

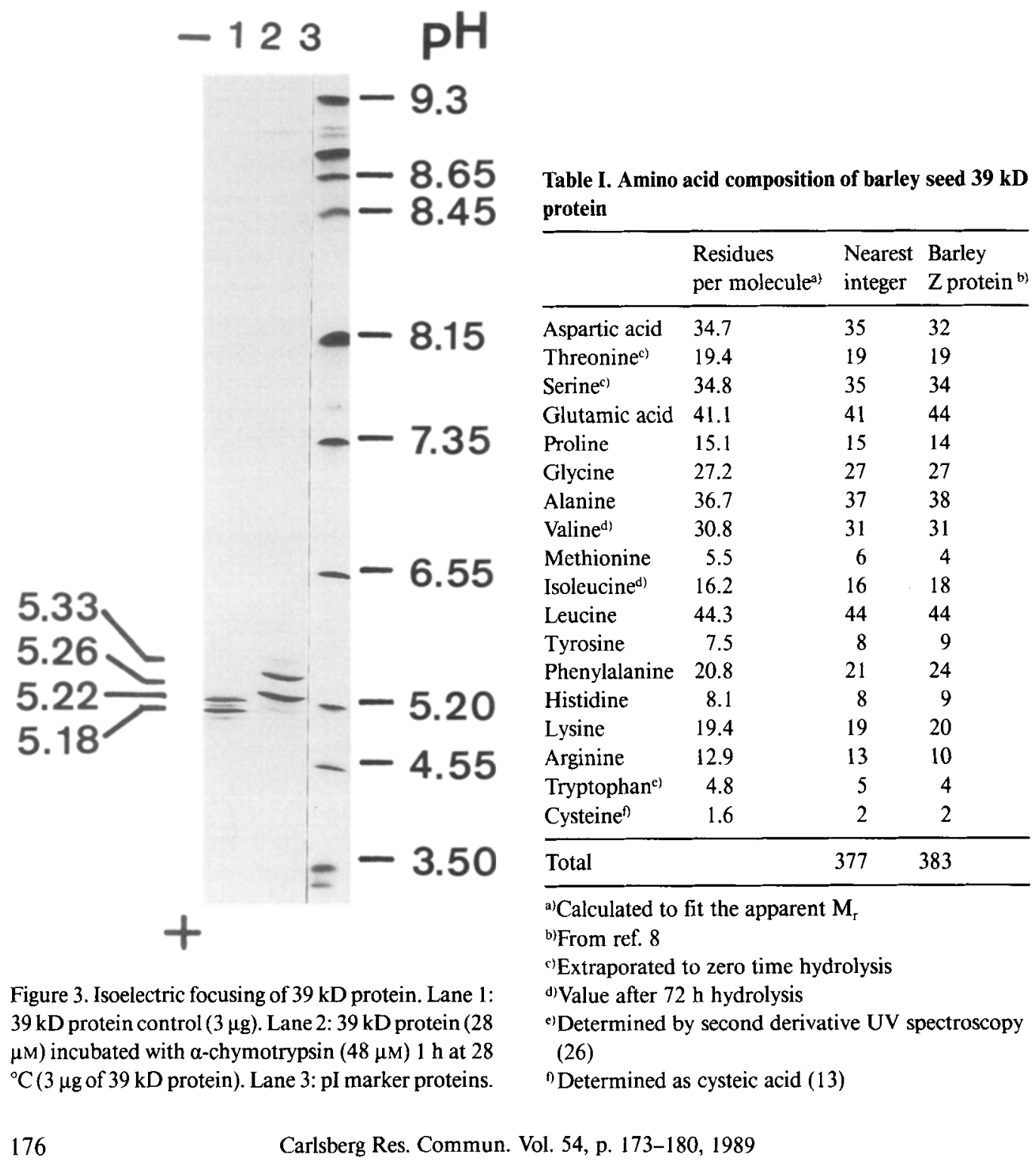




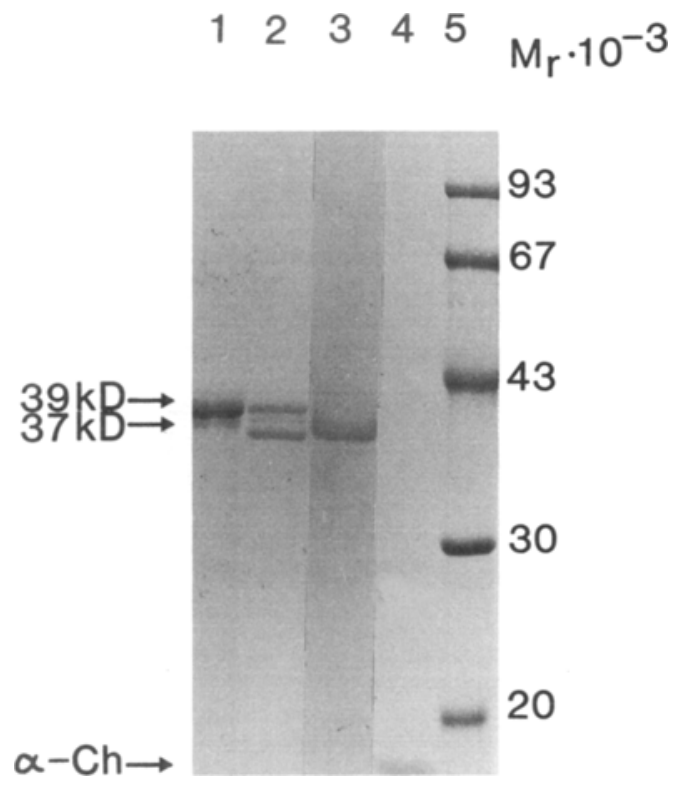

Figure 4. SDS-PAGE of $39 \mathrm{kD}$ protein. Lane 1: $39 \mathrm{kD}$ protein control $(5 \mu \mathrm{g})$. Lane $2: 39 \mathrm{kD}$ protein $(21 \mu \mathrm{M})$ incubated with $\alpha$-chymotrypsin $(7 \mu \mathrm{M}) 1 \mathrm{~h}$ at $21^{\circ} \mathrm{C}(10$ $\mu \mathrm{g}$ of $39 \mathrm{kD}$ protein). Lane $3: 39 \mathrm{kD}$ protein incubated with $\alpha$-chymotrypsin as for lane 2 Figure $3(10 \mu \mathrm{g}$ of 39 $\mathrm{kD}$ protein). Lane 4: $\alpha$-chymotrypsin $(\alpha-\mathrm{Ch})(20 \mu \mathrm{g})$. Lane 5: $M_{r}$ marker proteins.

values from 5.55 to 5.8 according to an earlier report (8). The $39 \mathrm{kD}$ has almost the same size as the $\mathrm{Z}$ protein (Table I) and is like the $\mathrm{Z}$ protein not a glycoprotein. Direct sequencing of the 39 $\mathrm{kD}$ protein $(23 \mathrm{nmol})$ showed homology to the $\mathrm{Z}$ protein from Ser360 (Fig. 2a), which is the

Table II. Inhibition of $\alpha$-chymotrypsin by $39 \mathrm{kD}$ barley seed protein

\begin{tabular}{lll}
\hline $\begin{array}{l}39 \mathrm{kD}: \alpha \text {-chymo- } \\
\text { trypsin } \\
(\mathrm{mol}: \mathrm{mol})\end{array}$ & $\begin{array}{l}\text { Esterase } \\
\text { activity } \\
\%\end{array}$ & $\begin{array}{l}\text { Endoproteinase } \\
\text { activity } \\
\%\end{array}$ \\
\hline 0 & 100 & 100 \\
1.4 & 89 & 89 \\
3.0 & 40 & - \\
7.0 & 41 & 44 \\
14.0 & 20 & - \\
\hline
\end{tabular}

The $39 \mathrm{kD}$ protein and a-chymotrypsin $(3 \mu \mathrm{M})$ were preincubated $1 \mathrm{~h}$ at $22{ }^{\circ} \mathrm{C}$ prior to assay of enzyme activity.
Table III. Effect of $\mathrm{pH}$ on the inhibitory activity of 39 kD barley seed protein

\begin{tabular}{ll}
\hline $\mathrm{pH}$ & $\begin{array}{l}\text { Activity } \\
\text { (\% of control) }\end{array}$ \\
\hline 4.0 & 100 \\
5.2 & 59 \\
7.3 & 47 \\
8.0 & 40 \\
9.0 & 50 \\
\hline
\end{tabular}

A three-fold molar excess of $39 \mathrm{kD}$ protein was incubated with $\alpha$-chymotrypsin $(3 \mu \mathrm{M})$ at the indicated $\mathrm{pH}$ values for $2 \mathrm{~h}$ at $25^{\circ} \mathrm{C}$ prior to assaying for esterase activity at $\mathrm{pH}$ 8.0. A separate control with $\alpha$-chymotrypsin alone was incubated at each $\mathrm{pH}$ value and assayed. The following buffers all $1 \mathrm{mM}$ in $\mathrm{CaCl}_{2}$ were used: $\mathrm{pH} 4.0$ and 5.2, $30 \mathrm{~mm}$ sodium acetate; $\mathrm{pH}$ 7.3, $30 \mathrm{~mm}$ 3-[N-morpholino]propanesulfonic acid; $\mathrm{pH}$ 8.0 and $9.0,30 \mathrm{~mm}$ Tris.

$\mathrm{N}$-terminus of the short C-terminal fragment. However, the yield of phenylthiohydantoins was about $2 \mathrm{nmol}$ which corresponds to approx. 9\% of the sample protein. Comparison with serpins suggests that it represents cleavage of the reactive center loop $(2,11,15)$. The $39 \mathrm{kD}$ protein was thus $\mathrm{N}$-terminally blocked like the barley $\mathrm{Z}$ protein (11) and the majority of the isolated molecules apparently remained uncleaved. A tryptic fragment (Fig. 2b) prepared from the 39 $\mathrm{kD}$ protein in $60 \%$ yield shows high homology confirming that the previously determined sequence was not due to a contaminant. At present about $50 \%$ of the primary structure has been identified (LundGaRd, SVEnSSON and SvendSEN, unpublished results) and shows $78 \%$ homology with the $Z$ protein (11).

\subsection{Interaction with $\alpha$-chymotrypsin}

$\alpha$-Chymotrypsin converted the $39 \mathrm{kD}$ protein into forms of higher pI, 5.26 and 5.33, and a polypeptide chain of $37 \mathrm{kD}$ (Figs. 3 and 4). In this product (Fig. 3, lane 2, and Fig. 4, lane 3) the serpin target bond (see Fig. 2a) was hydrolyzed in greater than $90 \%$ yield as estimated from sequence analysis. A few as yet unidentified peptide bonds were cleaved to a smaller extent, 
Table IV. Time course of inactivation of a-chymotrypsin by $39 \mathrm{kD}$ barley seed protein

\begin{tabular}{cl}
\hline $\begin{array}{l}\text { Preincubation } \\
\text { (min) }\end{array}$ & $\begin{array}{l}\text { Remaining activity } \\
\text { (\% of control) }\end{array}$ \\
\hline 0 & 100 \\
1 & 100 \\
5 & 74 \\
15 & 48 \\
70 & 39 \\
120 & 40 \\
\hline
\end{tabular}

$a$-Chymotrypsin $(3 \mu \mathrm{M})$ was incubated with three-fold molar excess of $39 \mathrm{kD}$ protein in $25 \mathrm{~mm}$ Tris, $1 \mathrm{~mm}$ $\mathrm{CaCl}_{2}, \mathrm{pH} 8.0$ at $22{ }^{\circ} \mathrm{C}$. Aliquots were removed at indicated time intervals for assay of residual esterase activity.

in agreement with observations on other proteinase treated serpins $(2,27)$.

The $39 \mathrm{kD}$ protein inhibited $\alpha$-chymotrypsin (Table II), whereas a 7.8 fold molar excess only reduced the activity of trypsin by $5-10 \%$ and seemed without effect on proteinase $K, S$. aureus V8 protease, thermolysin and two barley malt thiol endoproteinases. $\alpha$-Chymotrypsin inhibition was fairly constant in the range $\mathrm{pH}$ 5.2-9.0 and virtually not detectable at $\mathrm{pH} 4.0$ (Table III). The reaction was slow with about $15 \mathrm{~min}$ required for loss of half the esterase activity (Table IV). The estimated second-order rate constant of the complex formation, $\mathrm{k}_{\text {assoc }}=$ $10^{2}-6 \cdot 10^{2} \mathrm{M}^{-1} \cdot \mathrm{s}^{-1}$, is low, but comparable to values on physiologically relevant though relatively inefficient serpin-proteinase combinations such as $\alpha-1$-proteinase inhibitor with plas$\min (1,2,30)$. Isoelectric focusing or SDS-PAGE (Figs. 3 and 4) did not reveal an enzyme-39 kD protein complex in clear distinction to other serpin proteinase systems (30). Furthermore, pretreatment of $39 \mathrm{kD}$ protein at $\mathrm{pH} 3.0$ for 20 min at $22{ }^{\circ} \mathrm{C}$ that destroy inhibitory activity of the serpin $\alpha_{1}$-antitrypsin (30), or the presence of $1 \mathrm{mM} \mathrm{CaCl}_{2}$ or $50 \mathrm{~mm} \mathrm{NaCl}$ during incubation with $\alpha$-chymotrypsin neither reduced nor enhanced the inhibition. The activity of the $39 \mathrm{kD}$ protein was retained under vacuum centrifugation to dryness and redissolution, but lost by freezing of concentrated solutions or lyophilization. One might speculate, therefore, that the earlier demonstrated lack of inhibitory activity for the barley $\mathrm{Z}$ protein (11) is due to inactivating pretreatment of this protein.

\subsection{Immunochemical properties}

Immunodiffusion was performed using $39 \mathrm{kD}$ protein $(2-50 \mu \mathrm{g})$ and $\mathrm{IgG}(40-400 \mu \mathrm{g})$ directed against beer protein Fraction $X$ that is derived from barley $Z$ protein $(8,12)$. A resulting faint precipitate, that was detected between $2-15 \mu \mathrm{g}$ sample and $300-400 \mu \mathrm{g}$ of $\mathrm{IgG}$, could be slightly enhanced by pretreating the $39 \mathrm{kD}$ protein with $0.5 \%$ Triton $\mathrm{X}-100$ and/or heating at $80^{\circ} \mathrm{C}$ for $3 \mathrm{~min}$. With the same antibody barley extracts in contrast gave a sharp precipitate assumed to represent the $\mathrm{Z}$ protein $(7,8,12)$. Immunoadsorption chromatography of a Hiproly barley flour extract ( $\sim 150 \mathrm{mg}$ protein) on anti-beer protein Fraction X-IgG-Sepharose (see 2.2.1) confirmed the low reactivity since approx. 0.5 $\mathrm{mg}$ of pure $39 \mathrm{kD}$ protein appeared in the eluate, whereas applied purified beer protein Fraction $\mathrm{X}(5 \mathrm{mg})$, and probably also the $\mathrm{Z}$ protein from barley extracts, remained adsorbed. Purified 39 $\mathrm{kD}$ protein moreover failed to precipitate with antiserum to beer protein Fraction $X$ in rocket immunoelectrophoresis, whereas Fraction X itself reacted strongly (data not shown). Thus, perhaps only $39 \mathrm{kD}$ protein cleaved at the target-bond cross-reacts readily with $\mathrm{Z}$ protein and Fraction $X$ antibodies. Similarly, it has been reported that both of two $\mathrm{Z}$ protein types encoded by genes on barley chromosomes 4 and 7 , respectively (9) were recognized only by certain antibody preparations.

\section{DISCUSSION}

A $39 \mathrm{kD}$ protein isolated in much smaller amounts than the $Z$ protein (8) from aqueous extracts of barley flour also belongs to the serpin family based upon the evidence of amino acid composition, sequence homology and weak immunological cross-reactivity with the beer protein Fraction $X$, derived from barley $Z$ protein $(7,12)$. It probably represents an earlier observed protein which is encoded on barley chromosome 7 and immunochemically related to the $\mathrm{Z}$ protein from chromosome 4 (9). The 
proteinase inhibition involves limited proteolysis in a reactive center loop in serpins $(2,15)$ which in the isolated $39 \mathrm{kD}$ protein has been split to a significant, but low degree. The $39 \mathrm{kD}$ protein thus inhibits $\alpha$-chymotrypsin, whereas proteinase inhibition could not be demonstrated for $\mathrm{Z}$ protein preparations, already cleaved perhaps to a far greater extent (11). The $39 \mathrm{kD}$ protein, however, reacts slowly with $\alpha$-chymotrypsin compared with a variety of half-times reported for association of serine proteinases with serpins $(1,2,30)$, and it is uncertain whether it plays a role controlling a specific proteolytic activity related to either the plant defence against pathogens or the seed development and germination.

The serpin conformational transition from "strained" to "relaxed" (more stable) state triggered by limited proteolysis $(2,15,25,27)$ probably also occurs for the two superfamily members from barley. Thus in spite of the native $39 \mathrm{kD}$ protein being sensitive to e.g. freezing it retained antigenic sites throughout the brewing processes like the $\mathrm{Z}$ protein, as indicated by their respective immunological cross-reactivity to the beer protein Fraction X $(8,9,12)$. The knowledge of the mechanism and function of various evolutionary related serpin molecules $(1,2,15$, 27) and the present preliminary results on the interaction of $39 \mathrm{kD}$ protein and $\alpha$-chymotrypsin encourage the search for a target proteinase and physiological role of both this as well as the barley $\mathrm{Z}$ protein.

\section{ACKNOWLEDGEMENT}

We are indebted to Professor MARTIN OTTESEN for support throughout this study. Sincere thanks are due to Dr. KAREN SKRIVER for helpful critisism of the manuscript. Ms. EDITH FLøISTRUP is acknowledged for excellent technical assistance, Dr. IB SvendSEN, Mss. BodIL CORneliussen, Lone Sørensen and Pia Breddam for amino acid and sequence analyses and Dr. PIA VAAG, Carlsberg Research Laboratory, for the gift of anti-serum against beer protein Fraction $\mathrm{X}$.

\section{REFERENCES}

1. BEATTY, K., J. Bieth \& J. TRavis: Kinetics of association of serine proteinases with native and oxidized $\alpha-1$-proteinase inhibitors and $\alpha$-1-antichymotrypsin. J. Biol. Chem 255, 3931-3934 (1987)

2. CARrell, R.W., P.A. Pemberton \& D.R. BosWell: The serpins: evolution and adaptation in a family of protease inhibitors. Cold Spring Habor Symposia on Quantitative Biology LII, 527-535 (1987)

3. Dubois, M., K.A. Gilles, J.K. Hamilton, P.A. ReBERS\& F. SMITH: Colorimetric method for determination of sugars and related substances. Anal. Chem. 28, 350-356 (1956)

4. Flink, F., T.J. Bailey, T.A. Gustafson, B.E. MARKham \& E. Morkin: Complete amino acid sequence of human thyroxine-binding globulin deduced from cloned DNA: close homology to the serine antiprotease. Proc. Natl. Acad. Sci. 83, 7708-7712 (1986)

5. Garcia-Olmedo, F., G. Salcedo, R. SanchezMonge, L. Gomez, J. Royo \& P. CARbonero: Plant proteinaceous inhibitors of proteinases and $\alpha$ amylases. Oxford Surv. Plant Mol. Cell. Biol. 4, 275-334 (1987)

6. HAMMOND, G.L., C.L. SMITH, I.S. GoPING, D.H.UNDerhill, M.J. Harley, J. Reventos, N.A. Musto, G.L. GunSALUS \& C.W. BaRdiN: Primary structure of human corticosteroid binding globulin, deduced from hepatic and pulmonary cDNAs, exhibits homology with serine protease inhibitors. Proc. Natl. Acad. Sci. 84, 5153-5157 (1987)

7. HejgaARd, J.: "Free" and "bound" $\beta$-amylase during malting of barley. Characterization by two-dimensional immunoelectrophoresis. J, Inst. Brew. 84, 43-46 (1978)

8. HejgaARd, J.: Purification and properties of protein $\mathrm{Z}$ - a major albumin of barley endosperm. Physiol. Plant. 54, 174-182 (1982)

9. HejgaARD, J.: Gene products of barley chromosomes 4 and 7 are precursors of the major antigenic beer protein. J. Inst. Brew. 90, 85-87 (1984)

10. HejgaARD, J. \& S. Carlsen: Immunoelectrophoretic identification of a heterodimer $\beta$-amylase in extracts of barley grain. J. Sci. Fd. Agric. 28, 900-904 (1977)

11. Hejgatard, J., S.K. Rasmussen, A. Brandt \& I. SVENDSEN: Sequence homology between barley endosperm protein $Z$ and protease inhibitors of the $\alpha_{1}$-antitrypsin family. FEBS Lett. 180, 89-94 (1985)

12. HejgaARd, J.\& S.B. Sørensen: Characterization of a protein-rich beer fraction by two-dimensional immunoelectrophoretic techniques. Compt. Rend. Trav. Lab. Carlsberg 40, 187-203 (1975) 
13. HiRS, C.H.W.: Determination of cystine as cysteic acid. Meth. Enzymol. 11, 59-67 (1967)

14. HJELM, H.: Isolation of IgG3 from normal human sera and from a patient with multiple myelomatosis using protein A-Sepharose 4B. Scand. J. Immunol. 4, 633-640 (1975)

15. HUBER, R. \& R.W. CARRELL: Implications of the three-dimensional structure of $\boldsymbol{\alpha}_{1}$-antitrypsin for structure and function of serpins. Biochemistry 28 , 8951-8966 (1989)

16. HUNT, L.A. \& M.O. DAYHOFF: A surprising new protein superfamily containing ovalbumin, antithrombin III, and alpha ${ }_{1}$-proteinase inhibitor. Biochem. Biophys. Res. Commun. 95, 864-871 (1980)

17. Johansen, J.T., C. Overballe-Petersen, B. MarTIN, V. HASEMANN \& I. SVENDSEN: The complete amino acid sequence of copper,zinc superoxide dismutase from Saccharomyces cerevisiae. Carlsberg Res. Commun. 44, 201-207 (1979)

18. KageYama, R., H. OhKubo \& S. NAKanishi: Primary structure of human preangiotensinogen deduced from the cloned cDNA sequence. Biochemistry 23, 3603-3609 (1984)

19. KOEHLER,S.\& T.-H.D.Ho: Purification and characterization of gibberellic acid-induced cysteine endoprotease in barley aleurone layers. Plant Physiol. 87, 95-103 (1988)

20. LAEMMLI, U.K.: Cleavage of structural proteins during the assembly of the head of bacteriophage T4. Nature 227, 680-685 (1970)

21. LUNDGARD, R. \& B. SVENSSON: Limited proteolysis in the carboxy-terminal region of barley $\beta$-amylase. Carlsberg Res. Commun. 51, 487-491 (1986)

22. LUNDGARD, R. \& B. SVENSSON: The four major forms of barley $\beta$-amylase. Purification, characterization and structural relationship. Carlsberg Res. Commun. 52, 313-326 (1987)
23. Mahoney, W.C. \& M.A. Hermodson: Separation of large denatured peptides by reverse phase high performance liquid chromatography. Trifluoroacetic acid as a peptide solvent. J. Biol. Chem. 255, 11199-11203 (1980)

24. March, S.C., I. Parikh \& P. Cuatrecasas: A simplified method for cyanogen bromide activation of agarose for affinity chromatography. Anal. Biochem. 60, 149-152 (1974)

25. Pemberton, P.A., P.E. Stein, M.B. Pepys, J.M. PotTER \& R.W. CARRELL: Hormone binding globulins undergo serpin conformational change in inflammation. Nature 336, 257-258 (1988)

26. Servillo, L., G. Colonna, C. Balestrieri, R. RAGONE \& G. IRACE: Simultaneous determination of tyrosine and tryptophan residues in proteins by second-derivative spectroscopy. Anal. Biochem. 126, 251-257 (1982)

27. Stein, P.E., D.A. Tewkesbury \& R.W. Carrell: Ovalbumin and angiotensinogen lack serpin S-R conformational change. Biochem. J. 262, 103-107 (1989)

28. SVENDSEN,I., B. MARTIN \& I. JoNASSEN: Characteristics of Hiproly barley III. Amino acid sequences of two lysine-rich proteins. Carlsberg Res. Commun. $45,79-85$ (1980)

29. Svensson, B., K. LARSEn \& A. GUNNARSSON: Characterization of a glucoamylase G2 from Aspergillus niger. Eur. J. Biochem. 154, 497-502 (1986).

30. TRAVIS, J. \& G.S. SALVESEN: Human plama proteinase inhibitors. Ann. Rev. Biochem. 52, 655-709 (1983)

31. WALSH, K.A.: Trypsinogens and trypsins of various species. Meth. Enzymol. 19, 41-63 (1970)

32. WALSH, K.A. \& P.E. WILcoX: Serine proteases. Ibid., 41-63

33. WilCox, P.E.: Chymotrypsinogens - chymotrypsins. Meth. Enzymol. 19, 64-108 (1970)

Accepted by S.O. ANDERSEN 